\title{
DYNAMICS OF LIPID PROFILE AND BIOMARKERS OF SYSTEMIC INFLAMMATION IN WOMEN WITH INSULATED (INDEPENDENT) TYPE 2 DIABETES AND OBESITY OF DIFFERENT DEGREE
}

\author{
Mialiuk O. P., Shtrimaitis O. V., \\ Marushchak M. I., Sabadyshyn R. O.
}

\section{INTRODUCTION}

Type 2 diabetes (T2D) is a disease that remains one of the world's biggest problems. Its epidemic is becoming more and more widespread and pandemic, though more than a century has passed since the development of the first treatments for the disease. The patients quantity with T2D continues to increase, reaching 415 million people worldwide ${ }^{1}$. Insulin-dependent T2D contributes to body weight gain. Insulin, as an anabolic hormone, stimulates protein, glycogen, and lipid synthesis and suppresses lipolysis and proteolysis, and has a central effect on the appetite regulation. Insulininduced hypoglycemia stimulates appetite too, moreover, patients often overeat to prevent hypoglycemia, forming obesity ${ }^{2}$.

According to $\mathrm{WHO}$, a quarter of the planet's population is suffering from obesity or overweight. Most patients with T2D have obesity and overweight. The presence of obesity provokes the development and progression of T2D. Since the diagnosticating obesity requires long-term treatment. A decrease in body weight by $5-10 \%$ is associated with the glycemic control improvement, as well as with a decrease of risk factors of cardiovascular diseases development - insulin resistance, blood pressure, cholesterol and triglycerides, inflammation markers ${ }^{3}$.

There is a close relationship between type 2 diabetes (T2D) and obesity, a disease with inflammation, as adipose tissue has endocrine and paracrine

${ }^{1}$ IDF Diabetes Atlas. Available at https://www.diabetesatlas.org/en/ (issue, 2015).

2 Schwartz S., Herman M. Revisiting weight reduction and management in the diabetic patient: Novel therapies provide new strategies. J. Postgrad. Med. 2015. № 127(5). P. 480-493. doi: 10.1080/00325481.2015.1043182.

3 Standards of Medical Care in Diabetes - 2016. Obesity Management for the Treatment of Type 2 Diabetes. Diabetes Care. 2016. № 39. P. 47-51. doi: $10.2337 / \mathrm{dc} 16-$ S009. 
activity, producing cytokines ${ }^{4}$. Adipose tissue (AT) is a significant source of leptin, angiotensinogen, adiponectin, insulin-like growth factor, insulinbinding protein and monobutyrin, TNF-a, IL-6, plasmid, resistin, lipoprotein lipase, acetylation-stimulating proteins, cholesterol ethers-carrying proteins, retinol-binding protein, estrogens ${ }^{5}$. The purpose of our investigation was to study the lipid profile dynamics and the dependence of the inflammation intensity on the degree of women obesity with insulin-dependent (independent) T2D.

\section{Methods and materials}

For the study, 96 women from the endocrinological department of the Rivne Regional Specialized Health Center of Radiation Protection of the Rivne Regional Council with T2D have been examined, 76 people have different degrees of obesity between the ages of 38 and 49 years. The patients were divided into two groups: insulin-dependent and those who receive insulin replacement therapy. Women with independent T2D (66) were divided into groups according to the obesity degree based on BMI measurements, as defined in WHO recommendations.

The 1st group included people with insulin-independent T2D with normal body weight and waist circumference $(B M I=23,2 \pm 0,4 \mathrm{~kg} / \mathrm{m} 2$; $\mathrm{WC}=77,5 \pm 0,8 \mathrm{~cm})$; the 2nd group - with I degree obesity $(\mathrm{BMI}=34,6 \pm$ $0,4 \mathrm{~kg} / \mathrm{m} 2$ ); the 3rd group - with II degree obesity (BMI $=39,7 \pm$ $1,2 \mathrm{~kg} / \mathrm{m} 2$ ); the 4th group - with III degree obesity (BMI $=45,2 \pm$ $0,4 \mathrm{~kg} / \mathrm{m} 2$ ). Women with insulin-dependent T2D (30) were also divided into groups according to the obesity degree. The 1 st group included women with I degree obesity $(\mathrm{BMI}=32,6 \pm 1,0 \mathrm{~kg} / \mathrm{m} 2)$; the 2nd group - persons with II degree obesity $(\mathrm{BMI}=38,9 \pm 1,0 \mathrm{~kg} / \mathrm{m} 2)$; the $3 \mathrm{rd}$ group - persons with III degree obesity (BMI $=44,2 \pm 0,8 \mathrm{~kg} / \mathrm{m} 2)$. The control group consisted of 12 particularly healthy women aged 37-48 years $(\mathrm{BMI}=22,5 \pm$ $1,2 \mathrm{~kg} / \mathrm{m} 2 \mathrm{WC}=77,1 \pm 1,1 \mathrm{~cm})$.

During the anthropometric study, the height and weight of the patients were determined, BMI was calculated by dividing the body weight in $\mathrm{kg}$ into the square of growth in meters, WC was measured by a centimeter tape with an accuracy of $1,0 \mathrm{~cm}$. Indicators of blood lipid profile: total cholesterol

${ }^{4}$ Esser N., Legrand-Poels S., Piette J. et al. Inflammation as a link between obesity, metabolic syndrome and type 2 diabetes. Diabetes Res. Clin. Pract. 2014. № 105(2). P. 141-150. doi: 10.1016/j.diabres.2014.04.006.

5 Furuhashi M., Saitoh S., Shimamoto K. et al. Fatty Acid-Binding Protein 4 (FABP4): Pathophysiological Insights and Potent Clinical Biomarker of Metabolic and Cardiovascular Diseases. Clin. Med. Insights. Cardiol. 2015. № 2(8). P. 23-33. doi: 10.4137/CMC.S17067. 
(TC), triglycerides (TG), high density lipoprotein cholesterol (HDL), very low density lipoprotein cholesterol (LDL), and C-reactive protein (CRP) and glucose introduction (insulin dose of 2 units per $1 \mathrm{BU}$ of consumed food for insulin-dependent patients and metformin administration at a dose of 500 to $1500 \mathrm{mg}$ per day and exenatide at a dose of $5 \mu \mathrm{g} 2$ times a day for persons with insulin-independent T2D) was determined on an automatic biochemical analyzer HumaStar 600 (Austria) in Rivne Regional Clinical Hospital.

Low density lipoprotein cholesterol (LDL) was calculated by the Frivald formula: $\mathrm{LDL}=\mathrm{TC}-(\mathrm{HDL}-\mathrm{TG} / 2,2)$. Index of atherogenicity was calculated by the Klimov formula: IA $=(\mathrm{TC}-\mathrm{HDL}) / \mathrm{HDL}$. Hemogram parameters: the amount of hemoglobin, erythrocytes, and leukocytes were examined on an automatic hematological analyzer in "Maternity Hospital of Rivne City Council". The calculation of WCC (number of rod-core and segmented neutrophils, monocytes, lymphocytes, basophils) was performed in swabs stained by Romanovsky-Giemsa.

The proinflammatory cytokines (TNF- $\alpha$ and IL-6) concentration in blood serum was determined by the immunoenzyme method using the sets of reagents " $\alpha$-TNF-IFA-Best" and "Interleukin-6-IFA-Best" ("Vector Best", Russia). Measuring range of TNF- $\alpha 0-200 \mathrm{pg} / \mathrm{ml}$; set sensitivity $-2,0 \mathrm{pg} / \mathrm{ml}$. Measurement range of IL-6 $0-250 \mathrm{pg} / \mathrm{ml}$; set sensitivity $-0,5 \mathrm{pg} / \mathrm{ml}$. The fibrinogen (F) content was determined gravimetrically by the Rutberg method. Statistical analysis of the research results was carried out using Excel 2003 and Statistics for Windows (Statsoft Ins, USA). The probability level was determined by Student's criteria. The data are represented as $\mathrm{M} \pm \mathrm{m}$, results where $\mathrm{p}<0,05$ were considered to be reliable.

\section{Results and discussion}

According to our studies, women with independent T2D and normal body weight do not have significant deviations in lipid profile compared with the control group. The atherogenicity coefficient was on the verge of normal range. The glucose increase in 1,2 times $(p<0,05)$ in relation to particularly healthy persons was statistically significant which is normal according to the pathology of the studied people (Table 1). In the study of IL-6 content, which belongs to the main macrophage proinflammatory and pro-diabetic cytokines, has a powerful immunosuppressive effect, participates in the understudied and complex mechanisms of insulin secretion and consumption by different types of tissues ${ }^{6}$, above all, clear individual variations in the serum content of this adipokine were detected in the PC serum of all patient groups and controls.

${ }^{6}$ Allen T.L., Febbraio M.A. IL-6 as a mediator of insulin resistance: fat or fiction? Diabetologia. 2015. № 53(3). P. 399-402. 
In women with normal body weight and independent T2D an increase of IL-6 was observed in1,6 times ( $p<0,05)$, CRP $-2,4$ times $(\mathrm{p}<0,05)$, monocytes $-1,8$ times $(p<0,05)$. Our studies confirm the existing hypothesis that T2D is an inflammatory disease, since monocytosis, IL-6 growth, CRP, fibrinogen are markers of chronic low-intensity inflammation ${ }^{7}$. According to Table 1 and Table 2, patients with different obesity degrees had a gradual increase in biomarkers of systemic inflammation, which characterizes obesity as an inflammatory disease.

It was interesting to compare the lipidogram of insulin-dependent (independent) individuals with different obesity degrees. According to the data, insulin-dependent (dependent) women withT2D had significantly higher cholesterol content comparing with the stated value of subjects with I degree obesity. In insulin-independent women with II and III obesity degree, the value of cholesterol exceeded the control in 1,4-1,5 times and in insulinindependent women - by 1,3, regardless of BMI. LDL concentration was dependent on obesity degree, increasing relative to controls in 1,6 times in the 2nd group and in 1,7 times in the 3rd group.

A further increase in BMI at III obesity degree in women on the antihypertensive drugs (group 4) was accompanied by a 1,8-fold increase in LDL compared with controls, which, however, did not differ significantly from the indicator in group 3 (Table 1). Comparing the LDL content of women with insulin-dependent diabetes mellitus, it was found that in the 1st group the increase was significant and was 1,3 times higher than in the control, in the 2nd and 3rd group it was 1,4 times higher than in the control (Table 2). The data mentioned above show that the LDL level of people with CD2 who are on insulin therapy is reduced, so it gives us a possibility to suggest that the treatment effectiveness of the women with this pathology increases in this group.

Attention is drawn to the low level of HDL in individuals with I obesity, as well as an increase in WC more than $80 \mathrm{~cm}$, which is the main feature of central (visceral obesity). According to the recommendations of experts of the Russian Scientific Society of Cardiologists for the Diagnosis and Treatment of Metabolic Syndrome (2009), the main MS symptom of women is: WC more than $80 \mathrm{~cm}$, HDL content below $1,2 \mathrm{mmol} / \mathrm{l}$, increase in LDL more than $3,0 \mathrm{mmol} / \mathrm{l}$, hypertriglyceridemia greater than $1,7 \mathrm{mmol} / \mathrm{l}-$

7 Зак К.П., Комисаренко В.П. Роль нейтрофильных лейкоцитов в патогенезе сахарного диабета 1-го типа у человека (аналитический обзор с включением собственных данных). Международ. эндокринол. журнал. 2016. № 2(74). С. 130-139. 
additional MS criteria; the presence of central obesity and two additional criteria is the basis for diagnosing metabolic syndrome ${ }^{8}$.

Table 1

\section{Lipid profile and systemic inflammation biomarkers of women with non-insulin-dependent diabetes mellitus and obesity}

\begin{tabular}{|c|c|c|c|c|c|}
\hline $\begin{array}{c}\text { Groups } \\
\text { of patients }\end{array}$ & $\begin{array}{l}\text { Control } \\
\text { group, } \\
\mathrm{n}=12\end{array}$ & $\begin{array}{c}\text { 1st } \\
\text { group, } \\
\mathrm{n}=\mathbf{2 0}\end{array}$ & $\begin{array}{l}\text { 2nd } \\
\text { group, } \\
\mathrm{n}=12\end{array}$ & $\begin{array}{c}\text { 3rd } \\
\text { group, } \\
\mathrm{n}=19\end{array}$ & $\begin{array}{l}\text { 4th } \\
\text { group, } \\
\text { n=15 }\end{array}$ \\
\hline BMI, kg/m2 & $22,5 \pm 1,2$ & $\begin{array}{c}23,2 \pm \\
0,4\end{array}$ & $\begin{array}{c}34,6 \pm \\
0,4^{*}\end{array}$ & $\begin{array}{c}39,7 \pm \\
1,2^{*}\end{array}$ & $\begin{array}{c}45,2 \pm \\
0,4^{*}\end{array}$ \\
\hline $\mathrm{WC}, \mathrm{cm}$ & $77,1 \pm 1,1$ & $\begin{array}{c}77,5 \pm \\
0,8\end{array}$ & $\begin{array}{c}98,8 \pm \\
1,3^{*}\end{array}$ & $\begin{array}{c}108,5 \pm \\
1,2 *\end{array}$ & $\begin{array}{c}112,5 \pm \\
0,7 *\end{array}$ \\
\hline $\begin{array}{c}\begin{array}{c}\text { Glucose, } \\
\mathrm{mmol} / \mathrm{l}\end{array} \\
\end{array}$ & $4,7 \pm 0,2$ & $\begin{array}{l}5,7 \pm \\
0,2^{*} \\
\end{array}$ & $6,5 \pm 0,4$ & $7,7 \pm 0,4^{*}$ & $7,7 \pm 0,2$ \\
\hline $\mathrm{TG}, \mathrm{mmol} / \mathrm{l}$ & $0,86 \pm 0,15$ & $\begin{array}{c}0,94 \pm \\
0,13\end{array}$ & $\begin{array}{c}1,81 \pm \\
0,1^{*}\end{array}$ & $2,06 \pm 0,1$ & $\begin{array}{c}2,49 \pm \\
0,22\end{array}$ \\
\hline LDL mmol/l & $0,34 \pm 0,1$ & $\begin{array}{c}0,44 \pm \\
0,08\end{array}$ & $\begin{array}{l}0,84 \pm \\
0,08 *\end{array}$ & $\begin{array}{c}1,02 \pm \\
0,07\end{array}$ & $\begin{array}{c}1,37 \pm \\
0,1^{*}\end{array}$ \\
\hline $\begin{array}{c}\text { Cholesterol, } \\
\mathrm{mmol} / \mathrm{l}\end{array}$ & $4,0 \pm 0,3$ & $4,5 \pm 0,3$ & $\begin{array}{l}5,5 \pm \\
0,1^{*}\end{array}$ & $5,6 \pm 0,2$ & $5,9 \pm 0,1$ \\
\hline HDL mmol/l & $1,24 \pm 0,06$ & $\begin{array}{c}1,14 \pm \\
0,03\end{array}$ & $\begin{array}{l}0,80 \pm \\
0,05^{*}\end{array}$ & $0,76 \pm 0,1$ & $\begin{array}{c}0,77 \pm \\
0,12\end{array}$ \\
\hline LDL mmol/l & $2,42 \pm 0,23$ & $\begin{array}{c}2,98 \pm \\
0,19\end{array}$ & $\begin{array}{c}3,82 \pm \\
0,25^{*}\end{array}$ & $\begin{array}{c}3,98 \pm \\
0,09\end{array}$ & $\begin{array}{c}4,18 \pm \\
0,33\end{array}$ \\
\hline IA & $2,2 \pm 0,2$ & $\begin{array}{l}2,9 \pm \\
0,1^{*}\end{array}$ & $\begin{array}{l}5,9 \pm \\
0,3^{*}\end{array}$ & $6,4 \pm 0,2$ & $6,7 \pm 0,3$ \\
\hline IL-6, PG/ml & $6,1 \pm 1,0$ & $\begin{array}{c}10,0 \pm \\
0,9 *\end{array}$ & $\begin{array}{c}28,6 \pm \\
1,5^{*}\end{array}$ & $\begin{array}{c}38,3 \pm \\
1,1^{*}\end{array}$ & $\begin{array}{c}46,6 \pm \\
1,6^{*}\end{array}$ \\
\hline CRP, mg/l & $2,4 \pm 0,4$ & $\begin{array}{l}5,7 \pm \\
0,5^{*} \\
\end{array}$ & $\begin{array}{c}15,5 \pm \\
1,0^{*}\end{array}$ & $17,1 \pm 0,9$ & $18,5 \pm 0,2$ \\
\hline $\mathrm{F}, \mathrm{mg} / \mathrm{l}$ & $2844 \pm 122$ & $\begin{array}{c}3294 \pm \\
212\end{array}$ & $\begin{array}{c}3480 \pm \\
246\end{array}$ & $\begin{array}{c}3650 \pm \\
244\end{array}$ & $\begin{array}{c}3755 \pm \\
265\end{array}$ \\
\hline $\begin{array}{c}\text { Leukocytes } 10 \\
9 / 1\end{array}$ & $5,0 \pm 0,5$ & $5,5 \pm 0,1$ & $\begin{array}{l}6,4 \pm \\
0,3^{*}\end{array}$ & $6,6 \pm 0,5$ & $=0,5$ \\
\hline Monocytes, \% & $2,0 \pm 0,5$ & $\begin{array}{c}3,5 \pm \\
0,2^{*}\end{array}$ & $4,0 \pm 0,5$ & $6,0 \pm 0,5^{*}$ & $8,5 \pm 0,5^{*}$ \\
\hline
\end{tabular}

Note: ${ }^{*}-p<0,05-$ significance of differences between groups

${ }^{8}$ Урясьев О.М., Горбунова Д.Ю., Щербакова О.Н., Пыко А.А. Метаболический синдром - проблема медицины и современного общества. Вестник Смоленск. гос. мед. акад. 2017. № 16(1). С. 160-164. 
According to M.R. Salazar et al. (2014) an increase of WC more than $90 \mathrm{~cm}$ corresponds to the accumulation of visceral adipose tissue which has an area more than $130 \mathrm{~cm}^{2}$, the excess of this value is combined with metabolic disorders 9 . Thus, non-insulin-dependent women with 2 group diabetes had all the above mentioned MS criteria, while insulin-dependent women of group 1 (I level obesity) had no these characteristics. That is, insulin treatment of women with diabetes slows the development of MS, which is manifested according to the above data in II and III obesity degree.

Table 2

\section{Lipid profile and systemic inflammatory biomarkers in women} with insulin-dependent diabetes mellitus and obesity

\begin{tabular}{|c|c|c|c|c|}
\hline $\begin{array}{c}\text { Groups of } \\
\text { patients }\end{array}$ & $\begin{array}{c}\text { Control } \\
\text { group, } \mathbf{n}=\mathbf{1 2}\end{array}$ & $\begin{array}{c}\text { 1st group, } \\
\mathbf{= 1 1}\end{array}$ & $\begin{array}{c}\text { 2nd group, } \\
\mathbf{n = 1 1}\end{array}$ & $\begin{array}{c}\text { 3rd group, } \\
\mathbf{n = 8}\end{array}$ \\
\hline BMI, $\mathrm{kg} / \mathrm{m} 2$ & $22,5 \pm 1,2$ & $32,6 \pm 1,0^{*}$ & $38,9 \pm 1,0^{*}$ & $44,2 \pm 0,8^{*}$ \\
\hline $\mathrm{WC}, \mathrm{cm}$ & $77,1 \pm 1,1$ & $96,5 \pm 0,6^{*}$ & $107,3 \pm 0,9^{*}$ & $112,0 \pm 0,9^{*}$ \\
\hline Glucose, mmol/l & $4,7 \pm 0,2$ & $5,0 \pm 0,2$ & $5,5 \pm 0,3$ & $5,7 \pm 0,1$ \\
\hline $\mathrm{TG}, \mathrm{mmol} / \mathrm{l}$ & $0,86 \pm 0,15$ & $1,19 \pm 0,1$ & $1,61 \pm 0,14^{*}$ & $1,96 \pm 0,15$ \\
\hline HDL mmol/l & $0,34 \pm 0,1$ & $0,34 \pm 0,09$ & $0,54 \pm 0,04$ & $1,0 \pm 0,09^{*}$ \\
\hline $\begin{array}{c}\text { Cholesterol, } \\
\text { mmol/l }\end{array}$ & $4,0 \pm 0,3$ & $4,9 \pm 0,2^{*}$ & $5,1 \pm 0,1$ & $5,1 \pm 0,2$ \\
\hline ЛПВЩ, Mмоль/л & $1,24 \pm 0,06$ & $1,15 \pm 0,04$ & $0,95 \pm 0,03^{*}$ & $0,86 \pm 0,09$ \\
\hline LDL mmol/l & $2,42 \pm 0,23$ & $3,22 \pm 0,03^{*}$ & $3,40 \pm 0,1$ & $3,30 \pm 0,08$ \\
\hline IA & $2,2 \pm 0,2$ & $3,3 \pm 0,3^{*}$ & $4,4 \pm 0,2^{*}$ & $4,9 \pm 0,3$ \\
\hline IL-6, PG/ml & $6,1 \pm 1,0$ & $9,8 \pm 1,0^{*}$ & $15,6 \pm 1,3^{*}$ & $29,3 \pm 1,4^{*}$ \\
\hline CRP, mg/l & $2,4 \pm 0,4$ & $9,9 \pm 0,6^{*}$ & $11,5 \pm 0,9$ & $13,1 \pm 0,9$ \\
\hline F, mg/l & $2844 \pm 122$ & $3293 \pm 212$ & $3377 \pm 218$ & $3654 \pm 232$ \\
\hline Leukocytes 10 9/1 & $5,0 \pm 0,5$ & $5,8 \pm 0,1$ & $6,0 \pm 0,2$ & $6,4 \pm 0,4$ \\
\hline Monocytes, \% & $2,0 \pm 0,5$ & $4,0 \pm 0,3^{*}$ & $4,7 \pm 0,3$ & $5,3 \pm 0,2$ \\
\hline
\end{tabular}

Note: $*-p<0,05-$ significance of differences between groups

Persons with non-insulin-dependent T2D in group 2 had a significant TG increase relative to control in 2,1 times and in insulin-dependent women with T2D, the increase in TG was statistically unreliable and increased in 1,4 times ( $p>0,05)$. Similar situation was observed for KA (Fig. 1). Comparing changes in LDL with T2D in women on insulin therapy, an increase in the indicator in group 3 was 2,9 times relative to the control group was accurate; in non-insulin-dependent women, this indicator (group 4) significantly increased in 4 times relative to control.

${ }^{9}$ Salazar M.R., Carbajal H.A., Espeche W.G. et al. Identification of cardiometabolic risk: visceral adiposity index versus triglyceride/HDL cholesterol ratio. Am. J. Med. 2014. № 127(2). P. 152-157. doi: 10.1016/j.amjmed.2013.10.012. 

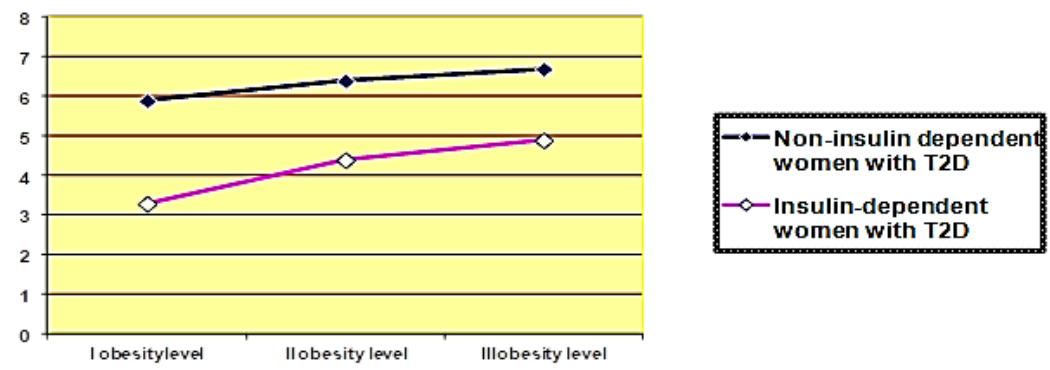

Fig. 1 Atherogenic factor in women with insulin-dependent (independent) T2D and different levels of obesity

According to L.S Litvinova et al. (2014), in II and III levels of obesity, there is no difference in the adispin level (a hormone of adipose tissue that regulates plasma TG levels and partially glucose). High concentration of TG in groups 3 and 4 in individuals with non-insulin-dependent diabetes mellitus, its increase in 2,4 and 2,9 times relative to the control group, as well as hyperglycemia, revealed in obesity of II and III levels in patients who did not use the insulin treatment may be due to adipsin resistance. Thus, all patients with insulin-independent diabetes mellitus 2 and obesity had hypertriglyceridemia, low HDL and dyslipidemia, which were characteristic only of the 2nd and 3rd groups of insulin-dependent patients.

As our results showed, increase in WC and dyslipidemia were combined with high levels of CRP and IL-6 as well as peripheral blood monocytosis, which is a sign of the systemic inflammatory response syndrome. The level of IL-6 in the 2nd group of non-insulin-dependent patients differed from the control, exceeding it in 4,7 times; in the $3 \mathrm{rd}$ and 4 th groups in 6,3 and 7,6 times, respectively, which turned out to be statistically accurate ( $p<0,05)$. In insulin-dependent patients with I obesity level, IL-6 levels significantly increased in 1,6 times relative to the control group, and in patients with II and III obesity levels in 2,4 and 4,8 times respectively.

IL-6 at high concentration induced CRP synthesis in the liver, which resulted in 7,7 times increase in its blood content compared with the control group in patients with non-insulin-dependent T2D (group 4) and 5,5 times in patients who had insulin treatment (group 3), which was found to be statistically unreliable compared to the neighbor groups. In 1 obesity level (Table 1), CRP was significantly increased in 6,5 times relative to control and 4,1 times in group 1 (Table 2). Fibrinogen level was not significantly different from control in all study groups; however, the maximum fibrinogen level in insulin-dependent women was lower. 
In the research comparing the content of monocytes in non-insulindependent women with diabetes mellitus, their number was maximally increased in 4,3 times in patients with III obesity level and in insulindependent women only in 2,7 times relative to the control. In patients on the tablet forms of the antipyretic drugs, monocyte growth was reliable relative to the control in all groups, while using insulin therapy monocyte growth was accurate only in the 1st group of patients. As monocytes are precursors of tissue macrophages, this indicates the development of tissue inflammation, which is more evident in non-insulin-dependent patients.

In this case, inflammation can develop in adipose tissue as well as in muscles, liver, pancreas, characterized by infiltration of macrophages and other immune cells which change their profile from anti-inflammatory to proinflammatory. The mechanisms underlying the initiation of adipose tissue infiltration by macrophages are unknown, although metabolic endotoxemia, nutritional induction and impaired signaling of adipocytes, local adipose tissue hypoxia, and increased glucose concentration are supposed to contribute $^{10}$. It was found in experiments that incubation of monocytes with high concentrations of leptin leads to a sharp increase in secretion by macrophages of proinflammatory cytokines: TNF-alpha and resistin, and increased production of IL-6 took place during incubation with high concentrations of glucose.

As our researches showed, the level of TNF-alpha in the blood varied widely: in non-insulin-dependent patients of the $2 \mathrm{nd}$, 3rd, 4th groups it was increased to 13 times relative to control. At the same time, in insulin-dependent patients of group 1, the level of TNF-alpha was within the allowable normal values $(0-6 \mathrm{pg} / \mathrm{ml})$, and in the $2 \mathrm{nd}$ and $3 \mathrm{rd}$ groups on the average it increased to 6-8 times and was $10,8 \pm 1,3 \mathrm{pg} / \mathrm{ml}$ relative to the control.

Discussing the obtained data, we note that the increase of TNF-alpha is considered by many researchers as a sign of insulin resistance in obesity, since the expression of TNF-alpha is most pronounced in adipocytes of visceral adipose tissue and its infiltrating macrophages. Therefore, according to our experiment, it can be assumed that insulin therapy inhibits the mechanisms of this cytokine growth, which slows the initiation of metabolic syndrome.

\section{CONCLUSIONS}

Thus, we came to the conclusion that hypertriglyceridemia and dyslipidemia were found, which were characteristic only of the 2nd and 3rd

10 Литвинова Л.С., Василенко М.А., Затолокин П.А. и др. Роль адипокинов в регуляции метаболических процессов при коррекции ожирения. Сахарн. диабет. 2014. № 3. C. 51-59. doi: 10.14341/DM2014351-59. 
groups of insulin-dependent patients, a dependence of changes in lipid profile on BMI and WC in patients with insulin-independent T2D and obesity was revealed. According to our study, there is a clear decrease in biomarkers of systemic inflammation in women with insulin-dependent diabetes mellitus at all obesity levels compared with those in non-insulindependent patients. Unlike insulin-dependent patients in the same group, manifestations of metabolic syndrome was not observed in women with I obesity level. Therefore, it can be assumed that insulin treatment reduces the systemic inflammation level and is more effective in slowing the development of metabolic syndrome in the early stages of obesity in the presence of T2D.

\section{SUMMARY}

There is a close relationship between type 2 diabetes (T2D) and obesity, a disease with inflammation, as adipose tissue has endocrine and paracrine activity, producing cytokines. Insulin, as an anabolic hormone, stimulates the synthesis of protein, glycogen, and lipids, and suppresses lipolysis and proteolysis, and has a central effect on the appetite regulation. Therefore, the purpose of our investigation was to study the lipid profile dynamics and the dependence of the inflammation intensity on the degree of women obesity with insulin-dependent (independent) T2D. 96 women with T2D have been examined, 76 of them have different degrees of obesity.

The patients were divided into two groups: insulin-dependent and those who receive insulin replacement therapy. We determined body mass index (BMI), waist circumference (WC), hemogram, lipid profile, biomarkers of inflammation and compared the results. Examining the lipidogram of the T2D and obesity patients with hypertriglyceridemia, low HDL and dyslipidemia were found, which were characteristic only of the 2nd and 3rd groups of insulin-dependent patients. The dependence of the lipid profile changes on BMI and WC was revealed.

The results showed that the increase in WC and dyslipidemia were combined with high levels of C-reactive protein (CRP), interleukin-6 (IL-6), and tumour necrosis factor alpha (TNF-a), as well as peripheral blood monocytosis, which is a sign of systemic inflammatory response syndrome. However, insulin therapy, according to our experiment, onset significantly reduced the level of inflammatory biomarkers and slowed the metabolic syndrome starts in the early stages of obesity.

\section{REFERENCES}

1. IDF Diabetes Atlas. Available at https://www.diabetesatlas.org/en/ (issue, 2015). 
2. Schwartz S., Herman M. Revisiting weight reduction and management in the diabetic patient: Novel therapies provide new strategies. J. Postgrad. Med. 2015. № 127(5). P. 480-493. doi: 10.1080/00325481.2015.1043182.

3. Standards of Medical Care in Diabetes - 2016. Obesity Management for the Treatment of Type 2 Diabetes. Diabetes Care. 2016. № 39. P. 47-51. doi: $10.2337 / \mathrm{dc} 16-$ S009.

4. Esser N., Legrand-Poels S., Piette J. et al. Inflammation as a link between obesity, metabolic syndrome and type 2 diabetes. Diabetes Res. Clin. Pract. 2014. № 105(2). P. 141-150. doi: 10.1016/j.diabres.2014.04.006.

5. Furuhashi M., Saitoh S., Shimamoto K. et al. Fatty Acid-Binding Protein 4 (FABP4): Pathophysiological Insights and Potent Clinical Biomarker of Metabolic and Cardiovascular Diseases. Clin. Med. Insights. Cardiol. 2015. № 2(8). P. 23-33. doi: 10.4137/CMC.S17067.

6. Allen T.L., Febbraio M.A. IL-6 as a mediator of insulin resistance: fat or fiction? Diabetologia. 2015. № 53(3). P. 399-402.

7. Зак К.П., Комисаренко В.П. Роль нейтрофильных лейкоцитов в патогенезе сахарного диабета 1-го типа у человека (аналитический обзор с включением собственных данных). Международ. эндокринол. журнал. 2016. № 2(74). Р. 130-139.

8. Урясьев О.М., Горбунова Д.Ю., Щербакова О.Н., Пыко А.А. Метаболический синдром - проблема медицины и современного общества. Вестник Смоленск. гос. мед. акад. 2017. № 16(1). С. 160-164.

9. Salazar M.R., Carbajal H.A., Espeche W.G. et al. Identification of cardiometabolic risk: visceral adiposity index versus triglyceride / HDL cholesterol ratio. Am. J. Med. 2014. № 127(2). P. 152-157. doi: 10.1016/j.amjmed.2013.10.012.

10. Литвинова Л.С., Василенко М.А., Затолокин П.А. и др. Роль адипокинов в регуляции метаболических процессов при коррекции ожирения. Сахарн. диабет. 2014. № 3. С. 51-59. doi: 10.14341/DM2014351-59.

\section{Information about the authors:} Mialiuk O. P.,

$\mathrm{PhD}$ in Biological Sciences, Head of the Educational-Methodical Laboratory, Teacher at the Department of Medical Prevention Disciplines and Laboratory Diagnostics Municipal Institution of Higher Education "Rivne Medical Academy" of Rivne Region Council 53, Karnaukhova str., Rivne, 33000, Ukraine 
Shtrimaitis O. V.,

$\mathrm{PhD}$ in Pharmaceutical Sciences, Vice-Rector, Teacher at the Department of Chemistry and Pharmaceutical Sciences Municipal Institution of Higher Education "Rivne Medical Academy" of Rivne Region Council 53, Karnaukhova str., Rivne, 33000, Ukraine

Marushchak M. I., Doctor in Medicine, Professor, Head of the Department of Functional and Laboratory Diagnostics Ivan Horbachevsky Ternopil National Medical University 1, Voli sq., Ternopil, 46002, Ukraine

Sabadyshyn R. O., Doctor of Medicine, Professor, Honored Doctor of Ukraine, Rector Municipal Institution of Higher Education "Rivne Medical Academy" of Rivne Region Council 53, Karnaukhova str., Rivne, 33000, Ukraine 